\title{
REVIEW
}

\section{An evidence-based review of aging of the body systems following spinal cord injury}

\author{
SL Hitzig ${ }^{1}$, JJ Eng ${ }^{2,3}$, WC Miller ${ }^{2,3}$ and BM Sakakibara ${ }^{2}$, the SCIRE Research Team \\ ${ }^{1}$ Lyndhurst Centre, Toronto Rehabilitation Institute, Toronto, Ontario, Canada; ${ }^{2}$ The GF Strong Rehabilitation Research Lab and the \\ Graduate Program in Rehabilitation Sciences, University of British Columbia (UBC), Vancouver, British Columbia, Canada and \\ ${ }^{3}$ International Collaboration On Repair Discoveries (ICORD), University of British Columbia (UBC), Vancouver, British Columbia, \\ Canada
}

\begin{abstract}
Study design: Systematic review.
Objective: To systematically review evidence on aging of the body systems after spinal cord injury (SCl). Setting: Toronto, Ontario and Vancouver, British Columbia, Canada.

Methods: Electronic databases (MEDLINE/PubMed, CINAHL, EMBASE and PsycINFO), were searched for studies published between 1980 and 2009. The search was augmented by reviewing the reference lists of relevant papers. Non-intervention studies that were longitudinal or cross-sectional with ablebodied controls that were at minimum matched on chronological age were included for review. Levels of evidence were assigned to the study design using a modified Sackett scale.

Results: Of the 74 studies selected for inclusion, 16 were longitudinal in design. The hypothesis that $\mathrm{SCl}$ represents a model for premature aging is supported by a large proportion of level 5 evidence for the cardiovascular and endocrine systems, level 2, 4 and 5 evidence for the musculoskeletal system, and limited level 5 evidence for the immune system. Only a few level 4 and 5 studies for the respiratory system were found. The evidence on the genitourinary system, gastrointestinal system, and for skin and subcutaneous tissues provide level 4 and 5 evidence that premature aging may not be occurring. The evidence on the nervous system does not provide evidence of premature aging as a result of $\mathrm{SCl}$.

Conclusions: Premature aging appears to occur in some systems after $\mathrm{SCl}$. Additional longitudinal studies are required to confirm these findings.
\end{abstract}

Sponsorship: Rick Hansen Institute; Ontario Neurotrauma Foundation.

Spinal Cord (2011) 49, 684-701; doi:10.1038/sc.2010.178; published online 14 December 2010

Keywords: spinal cord injuries; aging; body systems; longitudinal

\section{Introduction}

The literature suggests that persons with spinal cord injury (SCI) may be more susceptible to earlier age-related functional declines when compared with the able-bodied (AB) population, ${ }^{1}$ and that SCI represents a model for premature aging. ${ }^{2}$ Such premature aging of certain body systems has been said to occur because of additional stresses extending to physical systems beyond their ability to repair themselves. ${ }^{3}$ Although the aging process occurs at varying rates and at different ages for each individual, ${ }^{4}$ it is generally accepted that bodily functions reach a maximum capacity before or during early adulthood, before beginning to gradually decline. This decline is thought to commence at

Correspondence: Dr SL Hitzig, Lyndhurst Centre, Toronto Rehabilitation Institute, 520 Sutherland Drive, Toronto, Ontario, Canada M4G 3 V9. E-mail: hitzig.sander@torontorehab.on.ca

Received 1 July 2010; revised 15 October 2010; accepted 14 November 2010; published online 14 December 2010 approximately 25 years of age when the developmental process plateaus and biological capacity has peaked. ${ }^{5}$ This physical peak can be measured by examining the functioning of the individual organ systems (for example, cardiovascular capacity via how well the heart can pump blood) or by assessing the individual's maximum functional abilities (for example, amount of weight that can be lifted). After this peak, the body's reserve capacity of its organ systems begins to drop at a rate of $1 \%$ per year in $\mathrm{AB}$ persons. Thus, the average person at age 70 has about $50 \%$ of his/her capacity remaining in each organ system, which does not necessarily present a problem because all organ systems have 'excess reserve' (that is, more cells, structure and supportive tissue than is required to meet daily life needs). ${ }^{6}$ When reserve capacity diminishes to below $40 \%$ of original functioning, however, there is greater chance of becoming injured, and/or more susceptible to infection or disease. ${ }^{6}$ A SCI results in physiological and functional changes, and potentially 
accelerates bodily declines at approximately the time of injury, after which the effect of aging is said to proceed at a normal rate. ${ }^{7}$

Age of SCI-onset may have important consequences on different aspects of health. As there are increasing numbers of seniors incurring a SCI because of falls, a bi-modal age-ofonset distribution exists, with the prevalence of SCI peaking among individuals who are 30 and 60 years of age. ${ }^{8}$ As a result, researchers have been able to investigate and compare age-related outcomes after SCI. For example, there are a number of studies showing that persons who incur a SCI at later ages have poorer functional outcomes than those injured at younger ages. ${ }^{9-11}$ Within a theoretical reserve capacity model of aging that is disrupted by SCI, Adkins ${ }^{7}$ posits that the impact of injury 'decreases the further out on the age continuum the injury occurs' (p. 5). However, if the injury occurs far enough along the continuum, then even a minimal change in rate will lower reserve capacity below $40 \%$ because capacity is already low. Further, adults with older ages of SCI-onset may have other pre-existing comorbidities that affect outcomes compared with younger adults. $^{9}$

Fortunately, increases in life expectancy are providing opportunities to clarify the changes to body systems resulting from SCI, aging or both. What is clear is that physiologic systems do deteriorate with age, and this has been well documented in person with SCI. ${ }^{3,10}$ They may experience upper limb extremity pain, ${ }^{11,12}$ rapid bone loss in the lower extremities (that is, hips and knees) ${ }^{13}$ develop multiple risk factors for cardiovascular disease, ${ }^{14,15}$ experience declines in pulmonary function, ${ }^{16}$ and have recurring problems with the genitourinary ${ }^{17}$ and gastrointestinal ${ }^{18}$ systems.

The breadth of aging-related issues after SCI is expansive, and there is substantial overlap from body system to body system. Indeed, difficulties in one area impacts others, resulting in compromised system functioning. ${ }^{19}$ Presently, we have a naïve understanding what it means to live long term with SCI, but the field is now at a point where the evidence to-date can be systematically evaluated to better understand issues associated with aging following SCI. Hence, the purpose of this evidence-based review is to clarify the role of age (including age of SCI onset) and years postinjury (YPI) on outcomes, and to determine if premature aging is occurring for each physiological system.

\section{Materials and methods}

A systematic review of all relevant literature published from 1980 through to the end of December 2009 was conducted using multiple databases (MEDLINE/PubMed, CINAHL, EMBASE and PsycINFO). ${ }^{20}$ The key word 'spinal cord injuries' and its variants were used with the following terms: aging, longitudinal, prospective and case-control. Reference lists of relevant articles were reviewed and authors' names that came up frequently were targeted to augment the search. The articles considered for review were English non-intervention studies that had adult ( $>18$ years) SCI participants with traumatic etiologies comprising at least $50 \%$ of the sample.

With the intention of addressing aging of the body systems after SCI, studies that were longitudinal (including retrospective cohort data) or prospective in design that had observations of at least 2 years or more were included for review. However, association studies were excluded. In order to address the issue of premature aging, cross-sectional studies with an $\mathrm{AB}$ comparison group that was minimally matched on chronological age were also included. Case studies or studies with limited age ranges (that is, only persons in their twenties and/or early thirties, and so on) were excluded except for monozygotic twin model designs because this design provides some independence from genetic variability and aging.

After reviewing the abstracts and identifying papers for inclusion, a quality assessment was conducted on each relevant article using the Downs and Black tool. ${ }^{21}$ This assessment tool consists of 27 questions that evaluate the study's external and internal validity (both bias and confounding). The last question was modified from a scale of $0-5$ to a scale of $0-1$, where a study was provided with a score of 1 if a power calculation or sample size calculation was present. Conversely, a score of 0 was assigned if there was no power calculation, sample size calculation or explanation on whether the number of subjects was appropriate. Thus, the highest score any reviewed article could receive was 28 , with a higher score indicating higher methodological quality. ${ }^{21}$ Two independent reviewers assessed the quality of the studies. Discrepancies in scores were resolved by a third reviewer. Five levels of evidence, based on a modified scale, were used to rank the data ${ }^{22}$ (see Table 1).

\section{Results}

This search involved reviewing over 17000 titles and 8400 abstracts. Seventy-four articles met the inclusion criteria. The articles were categorized according to seven body systems: cardiovascular and endocrine systems $(n=24)$, immune system $(n=2)$, musculoskeletal system $(n=25)$, respiratory system $(n=4)$, skin and subcutaneous tissues $(n=2)$, genitourinary and gastrointestinal systems $(n=16)$, and nervous system $(n=4)$. It should be noted that some articles overlap across categories. The results presented from each study primarily focus on the analyses relevant to aging, and the $P$-values reported in Tables $2-8$ are those reported in the original articles.

\section{Cardiovascular system}

Fifteen studies were identified for the cardiovascular systems (see Table 2). There is level 5 evidence that plasma homocysteine levels are higher in persons with SCI $(n=835)$ compared with the $\mathrm{AB}$ population $(n=14838)$, with discrepancies greatest in older adults with SCI $(>50$ years). ${ }^{23}$ Elevated levels of plasma homocysteine have been shown to be a clear marker for the prediction of vascular disease, although it is unclear if it is the main cause or only an associated factor. ${ }^{24,25}$ 
Table 1 Modified levels of evidence

\begin{tabular}{ll}
\hline $\begin{array}{l}\text { Evidence } \\
\text { level }\end{array}$ & Description \\
\hline Level 1 & $\begin{array}{l}\text { Not applicable given there are no studies with a design that is } \\
\text { equivalent to a randomized controlled trial. } \\
\text { Lengitudinal studies that include a control group (for } \\
\text { example, AB group) as they are considered cohort studies } \\
\text { where one group is exposed to a particular condition } \\
\text { (in this case, a SCl). }\end{array}$ \\
Level 3 & $\begin{array}{l}\text { Longitudinal studies which include historical controls } \\
\text { (from chart review or database) }\end{array}$ \\
Level 5 & $\begin{array}{l}\text { Longitudinal studies including at least a baseline and follow- } \\
\text { up evaluation (at least equivalent to before-after studies). } \\
\text { and AB controls at one point in time. }\end{array}$
\end{tabular}

Abbreviations: $\mathrm{AB}$, able-bodied; $\mathrm{SCl}$, spinal cord injury.

There is conflicting level 5 evidence from several studies demonstrating that persons with SCI have abnormal lipid profiles $^{2,26-33}$ with some studies ${ }^{27,32,33}$ reporting that total cholesterol/high-density lipoprotein levels, total cholesterol $^{33}$ and low-density lipoprotein ${ }^{33}$ were higher in persons with SCI than in AB controls, while others ${ }^{2,27-29,32}$ found that total cholesterol, high-density lipoprotein and lowdensity lipoprotein levels were lower. It is possible that lifestyle factors may have accounted for differences across these studies, but further work is needed to clarify the role of diet and physical activity to aging with SCI.

Another study provides level 5 evidence that C-reactive protein levels are higher in men with SCI $(n=62)$ compared with $\mathrm{AB}$ controls $(n=29)$, which could also account for the decreases in total cholesterol, low-density lipoprotein and high-density lipoprotein. ${ }^{29}$ At the same time, increases in C-reactive protein levels may also partly explain why persons with SCI are nonetheless at increased risk for accelerated atherogenesis. ${ }^{32}$ As well, one study provided level 5 evidence that persons with SCI $(n=144)$ also have greater atherosclerotic burden compared with an $\mathrm{AB}$ reference population $(n=273)$ (Orakzai et al. $\left.{ }^{34}\right)$.

Finally, two studies provide level 5 evidence that when compared with $\mathrm{AB}$ controls, men with complete $\mathrm{T} 6$ or above paraplegia $(n=50)$ have an abnormal (absent) heart rate response during exercise, and men with complete tetraplegia $(n=7)$ have increased mean arterial blood pressure. ${ }^{3,36}$ These findings are indicative of altered autonomic control, and may contribute to changes in cardiovascular health.

\section{Endocrine system}

Thirteen studies were identified for the endocrine system (See Table 2). There is level 5 evidence that secretion of testosterone and human growth hormone levels are lower in persons with SCI compared with AB controls. ${ }^{37-40}$ Level 5 evidence from two studies ${ }^{37,41}$ suggests that serum insulinlike growth factor 1 levels are impaired in persons with SCI compared with the $\mathrm{AB}$ population, and may be a sign of premature aging. There is also level 5 evidence that glucose tolerance is lower after SCI, ${ }^{2,29,42}$ which concurs with level 5 evidence that diabetes mellitus occurs prematurely in men with SCI $(n=3708)$ compared with AB controls $(n=18018)$ (Lavela et al. ${ }^{43}$ ). There is level 5 evidence that persons with SCI have higher levels of fat mass, and experience significantly faster rates of age-related declines of lean tissue, than in the $\mathrm{AB}$ population. ${ }^{26,27,42,44-46}$ Finally, there is level 5 evidence that basal and resting energy expenditures are lower in men with SCI $(n=13)$ compared with their AB twin. ${ }^{47}$

\section{Immune system}

Two studies on the immune system after SCI (see Table 3) provide level 5 evidence that this system is compromised at both the acute and chronic stage of SCI compared with the $\mathrm{AB}$ population. ${ }^{48,49}$

\section{Musculoskeletal system}

Twenty-five articles were identified relevant to the musculoskeletal system (see Table 4), which support the notion of premature aging in most areas with a few exceptions. There is level 4 evidence ${ }^{50-52}$ and level 5 evidence ${ }^{53-63}$ that there is a rapid loss of bone in the hip and lower extremities following SCI, and that this bone loss is significantly lower than the $\mathrm{AB}$ population. Within these studies there are also some interesting patterns found in relation to chronological age and YPI with the extent and rate of system decline. For instance, three studies provide level 5 evidence that older men and women with SCI may not experience as rapid of a decline in bone mass compared with $\mathrm{AB}$ controls. ${ }^{57,60,62}$ Conversely, there is level 5 evidence that YPI may be more associated with bone loss after SCI than chronological age, ${ }^{53,57}$ therefore suggesting premature aging.

There is level 5 evidence that differences exist in bone geometric indices and in structural properties in the lower extremities of women with SCI $(n=19)$ compared with the $\mathrm{AB}$ women $(n=17)$ (Slade et al.$\left.^{59}\right)$. Level 5 evidence from five studies suggests that biochemical and bone markers in persons with SCI are impaired compared with $\mathrm{AB}$ controls, ${ }^{55,62,64-66}$ which contributes to a greater risk for fracture because of the premature development of osteoporosis. Conversely, there is level 2 (Catz et al. ${ }^{67}$ ) and level 5 (Chow et al. ${ }^{54}$; Garland et al. ${ }^{57}$; Szollar et al. ${ }^{60-62}$ evidence that premature aging does not occur in the lumbar spine after SCI. As well, one study provides level 5 evidence that persons with SCI, regardless of age or YPI, have increased thoracic kyphosis compared with $\mathrm{AB}$ controls. ${ }^{68}$ However, thoracic kyphosis may also be attributable to muscle changes (that is, innervated musculature).

With regard to the upper extremities, there is level 2 evidence showing that the incidence of shoulder pain increases over time in persons with SCI. ${ }^{69,70}$ This is supported by level 5 evidence that upper limb pain in men with complete paraplegia who use manual wheelchairs may be attributed to longer YPI and not to chronological age. ${ }^{71}$ However, there is also level $2\left(\mathrm{Lal}^{72}\right)$ and level 5 evidence ${ }^{73}$ that highlights chronological age as having an important influence on developing shoulder pain. Finally, there is level 5 evidence that premature aging does not occur in hand grip strength in men with complete paraplegia and that 


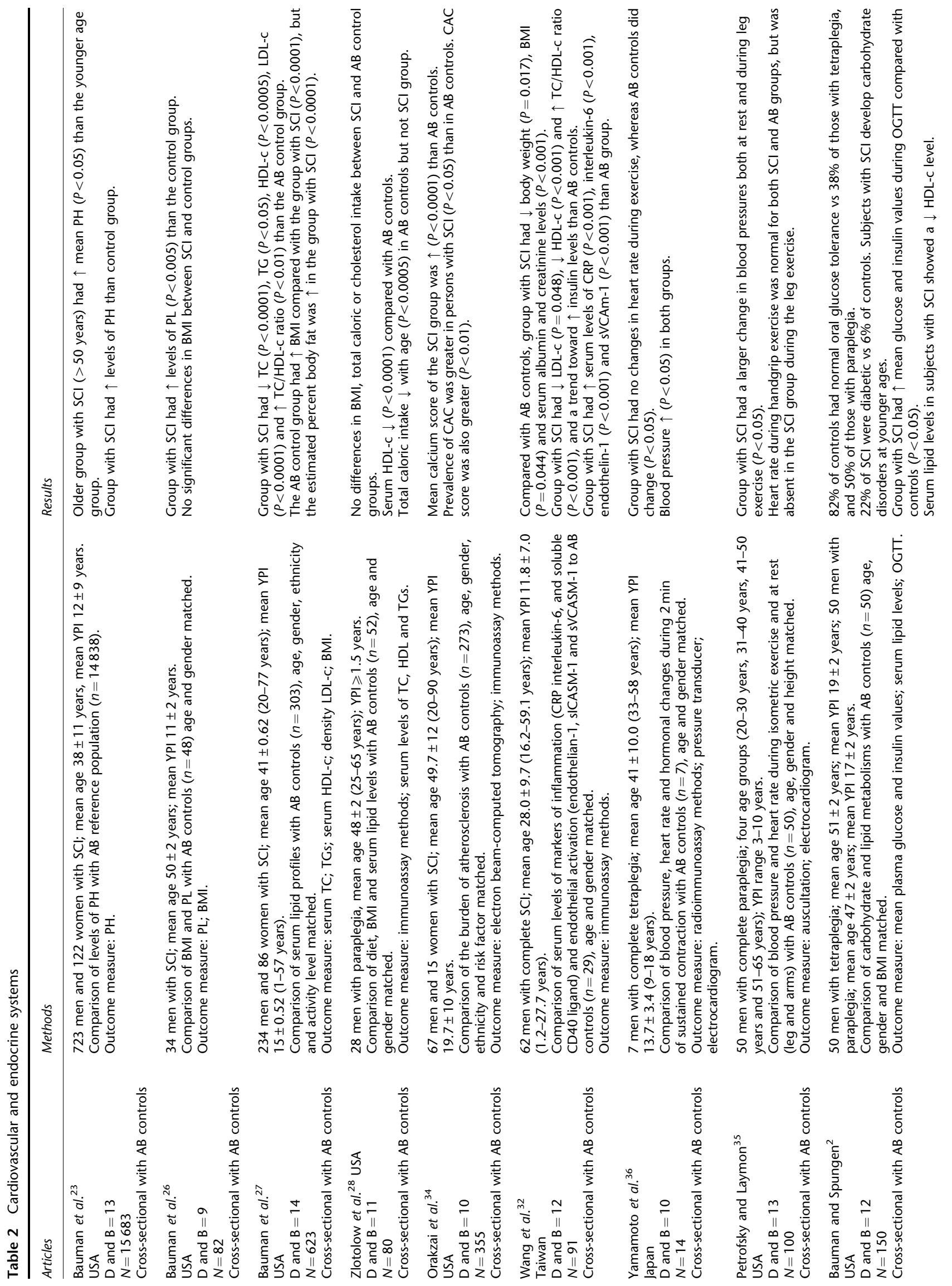




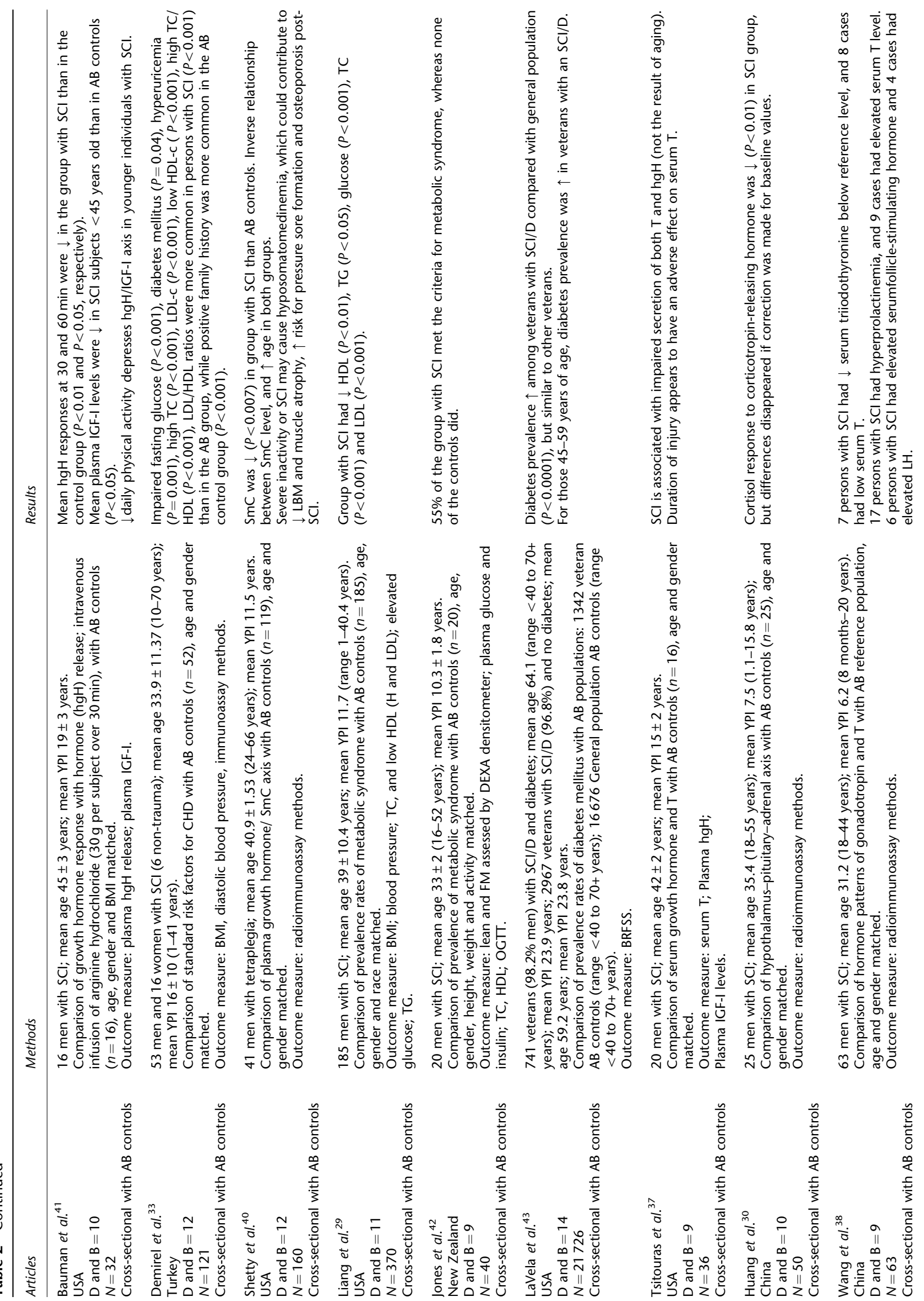




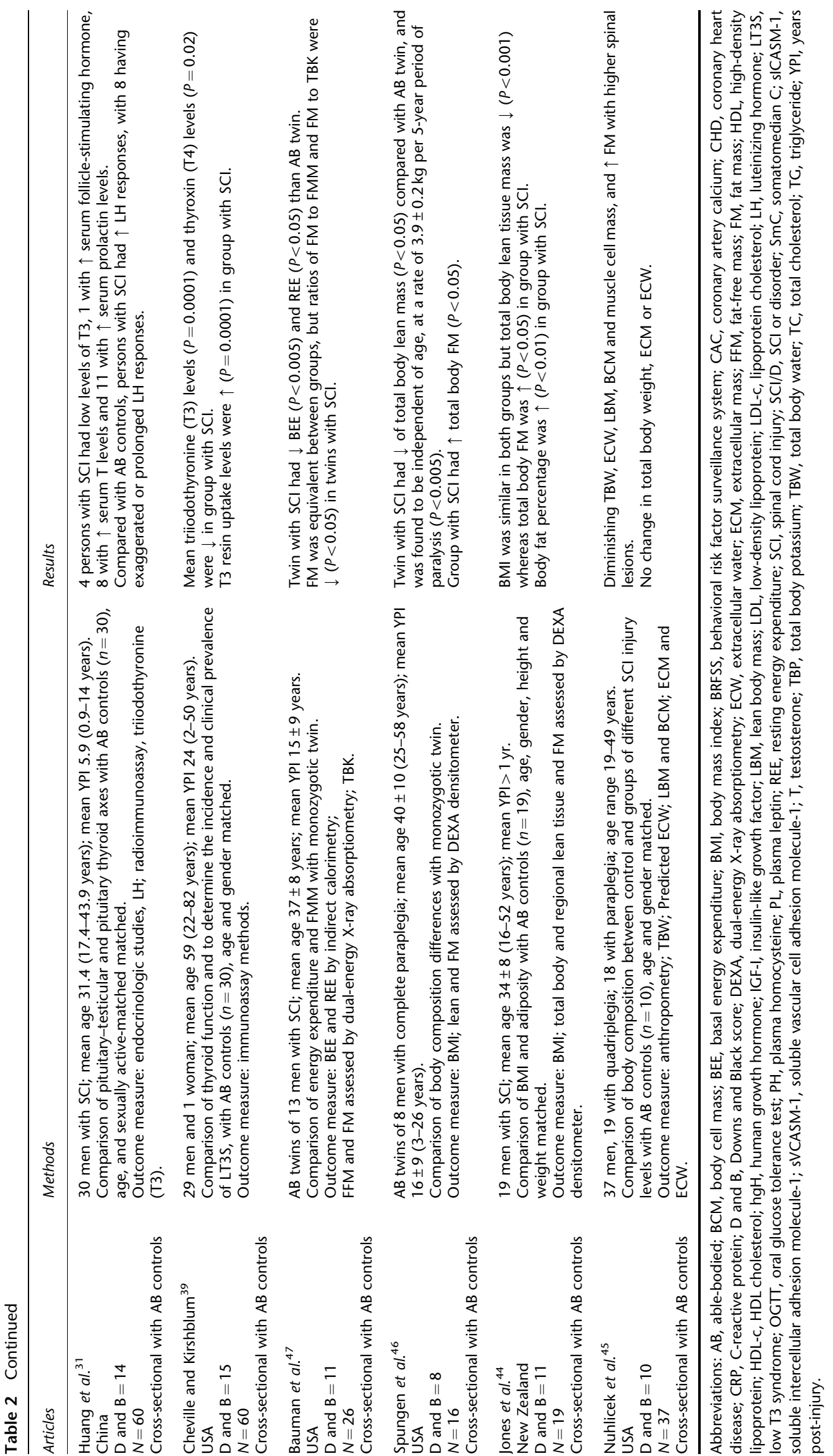


Table 3 Immune system

\begin{tabular}{|c|c|c|}
\hline Article & Methods & Results \\
\hline $\begin{array}{l}\text { Campagnolo et al. } \\
\text { USA } \\
D \text { and } B=11 \\
N=10 \\
\text { Cross-sectional with } A B \text { controls }\end{array}$ & $\begin{array}{l}4 \text { men and } 1 \text { woman with complete tetraplegia; } \\
\text { mean age } 36.2 \text { ( } 20-69 \text { years); mean YPI } 33.8 \\
\text { ( } 7-120 \text { months). } \\
\text { Comparison of an immunologic parameter, } \\
\text { and psychological well-being with AB controls } \\
(n=5) \text {, age and gender matched. } \\
\text { Outcome measure: lymphocyte proliferation assay; } \\
\text { natural killer cell cytotoxicity assay; cell counts; } \\
\text { llfeld psychiatric symptom index. }\end{array}$ & $\begin{array}{l}\text { No difference in cytometry, depression or stress. } \\
\text { Persons with } \mathrm{SCl} \text { had significant suppression in } \\
\text { lymphocyte balstogenic response for the three } \\
\text { mitogens tested (pokeweed, } P=0.039 \text {; conconavalin, } \\
P=0.038 \text {; phytohemagglutinin, } P=0.0008 \text { ). }\end{array}$ \\
\hline $\begin{array}{l}\text { Campagnolo et al. } \\
\text { USA } \\
D \text { and } B=12 \\
N=46 \\
\text { Cross-sectional with } A B \text { controls }\end{array}$ & $\begin{array}{l}11 \text { men and } 17 \text { women; for persons with tetraplegia, } \\
\text { mean age } 29 \text { ( } 19-51 \text { years), mean YPI } 56.6 \text { months; } \\
\text { for persons with paraplegia, mean age } 32.6 \\
\text { ( } 21-50 \text { years), mean YPI } 38.6 \text { months. } \\
\text { Comparison of pituitary and adrenal function with } \\
\text { AB controls ( } n=18) \text {, age and gender matched. } \\
\text { Outcome measure: immunoassay methods. }\end{array}$ & $\begin{array}{l}\text { Plasma cortisol and DS were } \uparrow(P=0.06 \text {, and } P=0.05 \text {, } \\
\text { respectively) in persons with } \mathrm{SCl} \text {. } \\
\text { When examined within level of injury, no differences } \\
\text { on mean plasma cortisol emerged, but persons with } \\
\text { tetraplegia had } \uparrow(P=0.05) \text { levels of mean plasma DS } \\
\text { than } A B \text { controls. }\end{array}$ \\
\hline
\end{tabular}

Abbreviations: AB, able-bodied; BMI, body mass index; D and B, Downs and Black score); DS, dehydroepiandrosterone sulfate; SCI, spinal cord injury; YPI, years post-injury.

continual manual wheelchair use may retard this aging process. $^{35,71}$

\section{Respiratory system}

Four studies on the respiratory system were identified (see Table 5). There is level 4 (Bach and Wang ${ }^{74}$ ) and level 5 evidence ${ }^{75,76}$ that sleep disordered breathing as characterized by sleep apnea, oxygen desaturation and snoring is more prevalent in SCI populations, and that it may either increase or persist with the aging process in persons with SCI. ${ }^{74}$ As well, one study relying on self-report found that persons with SCI $(n=408)$ snored more often, louder and commenced at a younger age than AB controls $(n=339)$ (BieringSorensen $\mathrm{F}$ and Biering-Sorensen $\mathrm{M}^{76}$ ), which could be interpreted as premature aging. Level of injury, however, likely has an important role given that another study found that six patients with tetraplegia $(n=16)$ had oxygen saturation levels below the normative range $(n=12)$ (Cahan et al. ${ }^{75}$ ). As well, there is level 5 evidence demonstrating that seated breathing patterns are compromised immediately post-injury in men with tetraplegia $(n=6)$ compared with $\mathrm{AB}$ controls $(n=18)$ but appear to recover over time. ${ }^{77}$

\section{Skin and subcutaneous tissues}

Two studies were identified on skin and subcutaneous tissues (see Table 6). There is level 2 evidence indicating that men with SCI $(n=10)$ have higher, albeit not significant, levels of a collagen metabolite, glu-gal Hyl, than AB controls $(n=5)$ (Rodriguez and Claus-Walker ${ }^{78}$ ) and level 4 evidence from a 2-year study that increased excretions of glu-gal Hyl is significantly associated with development of pressure ulcers in men with SCI $(n=62)$ (Rodriguez and Garber $\left.{ }^{79}\right)$.

\section{Genitourinary system}

Eleven studies were identified for the genitourinary system (see Table 7). There is level 4 evidence that up until five YPI, there are no differences in renal functioning, at which time functioning has been noticed to decline. ${ }^{80-82}$ One study provides level 4 evidence that repeated episodes of vesicoureteral reflux can cause kidney damage as early as four YPI in some persons with SCI $(n=32)\left(\operatorname{Lamid}^{83}\right)$. As well, there is level 4 evidence that renal plasma flow declines until $10 \mathrm{YPI}$ after SCI $(n=1114)$, at which time a slight reversal occurs. ${ }^{81}$ One level 5 study with SCI $(n=400)$ and AB groups $(n=287)$ suggests that age of onset may be an important factor related to renal functioning. ${ }^{84}$ It was shown that those individuals with SCI under 20 years of age or older than 50 had comparable renal functioning to the $\mathrm{AB}$ controls, whereas persons between those ages were more likely to have impaired functioning. Finally, there is level 5 evidence that men with SCI do not appear to be at higher risk for the development of prostate cancer compared with the general population, ${ }^{85-90}$ but when detected in persons with SCI $(n=7)$, the cancer may be more advanced and metastatic than in AB controls $(N=267)$ (Scott et al. $\left.{ }^{86}\right)$.

\section{Gastrointestinal system}

Five studies were identified for the gastrointestinal system (See Table 7). A 10-year longitudinal study provides level 4 evidence that persons with SCI $(N=159)$ do incur an increase in constipation-related symptoms over time. ${ }^{91}$ It may be that bowel functioning worsens over time for persons with SCI but three studies ${ }^{92-94}$ provide level 5 evidence that level of injury has a primary role in the extent of bowel dysfunction. As well, one study provides level 5 evidence that deterioration in bowel continence increases with age in an $\mathrm{AB}$ population $(n=467)$ but does not change in persons with SCI $(n=467)$ (Lynch et al. $\left.{ }^{95}\right)$.

\section{Nervous system}

Four studies (with SCI samples of $>70$; see Table 8 ) provide level 4 evidence that the early onset of SCI-related pain is likely to persist over time, ${ }^{69,70,96,97}$ and that the degree of interference experienced might be impacted by age of onset. $^{69}$ 


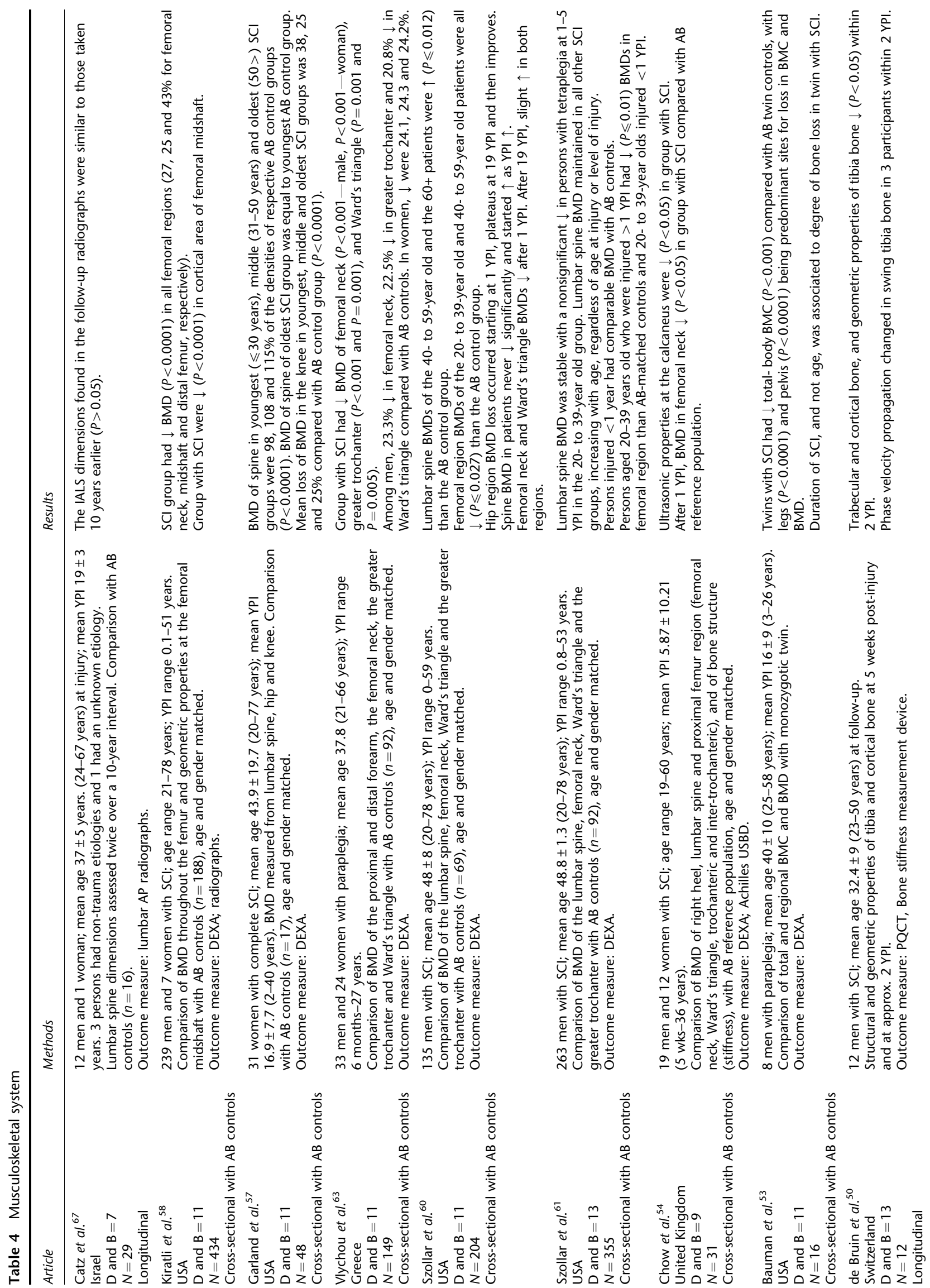




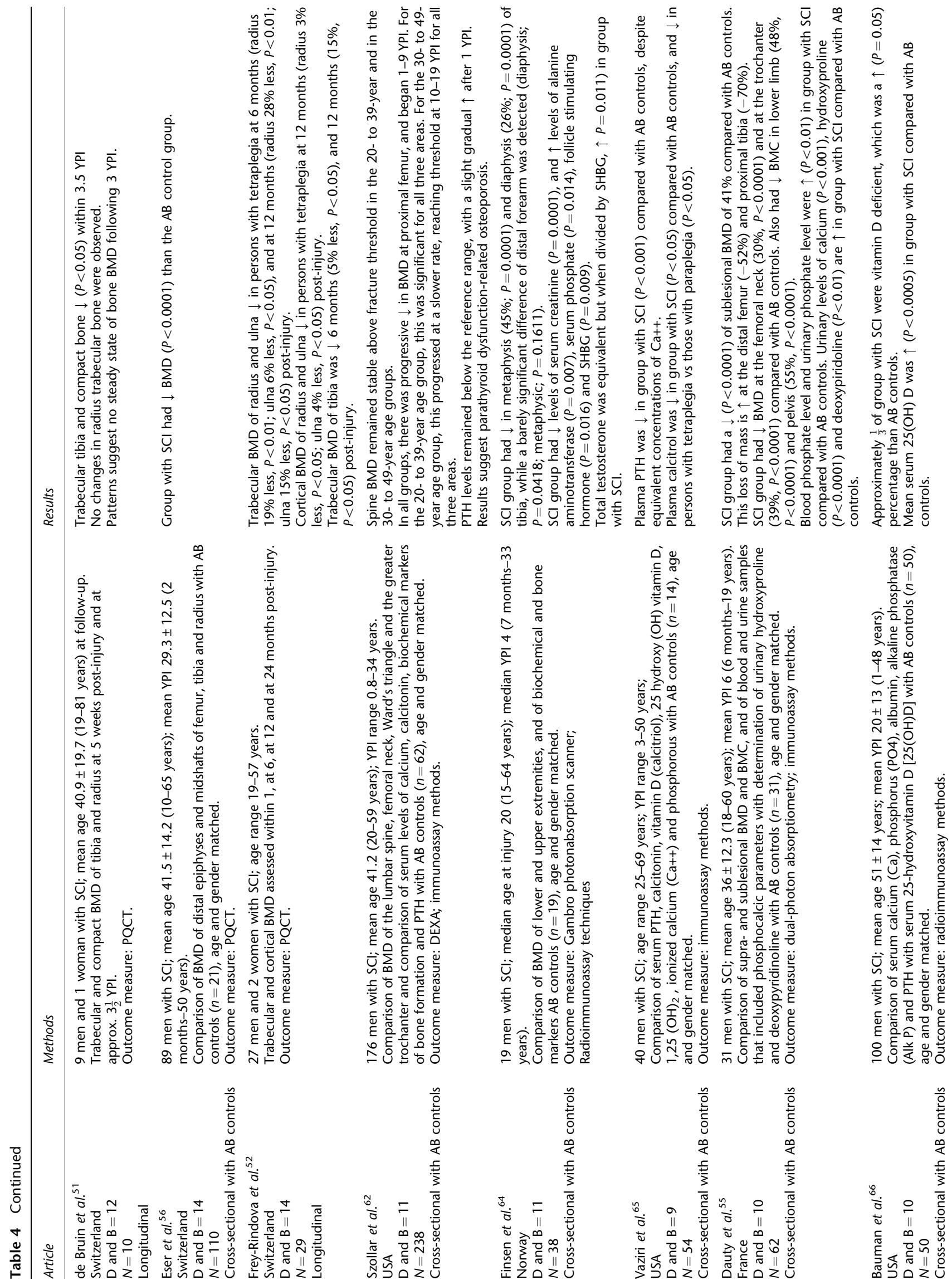




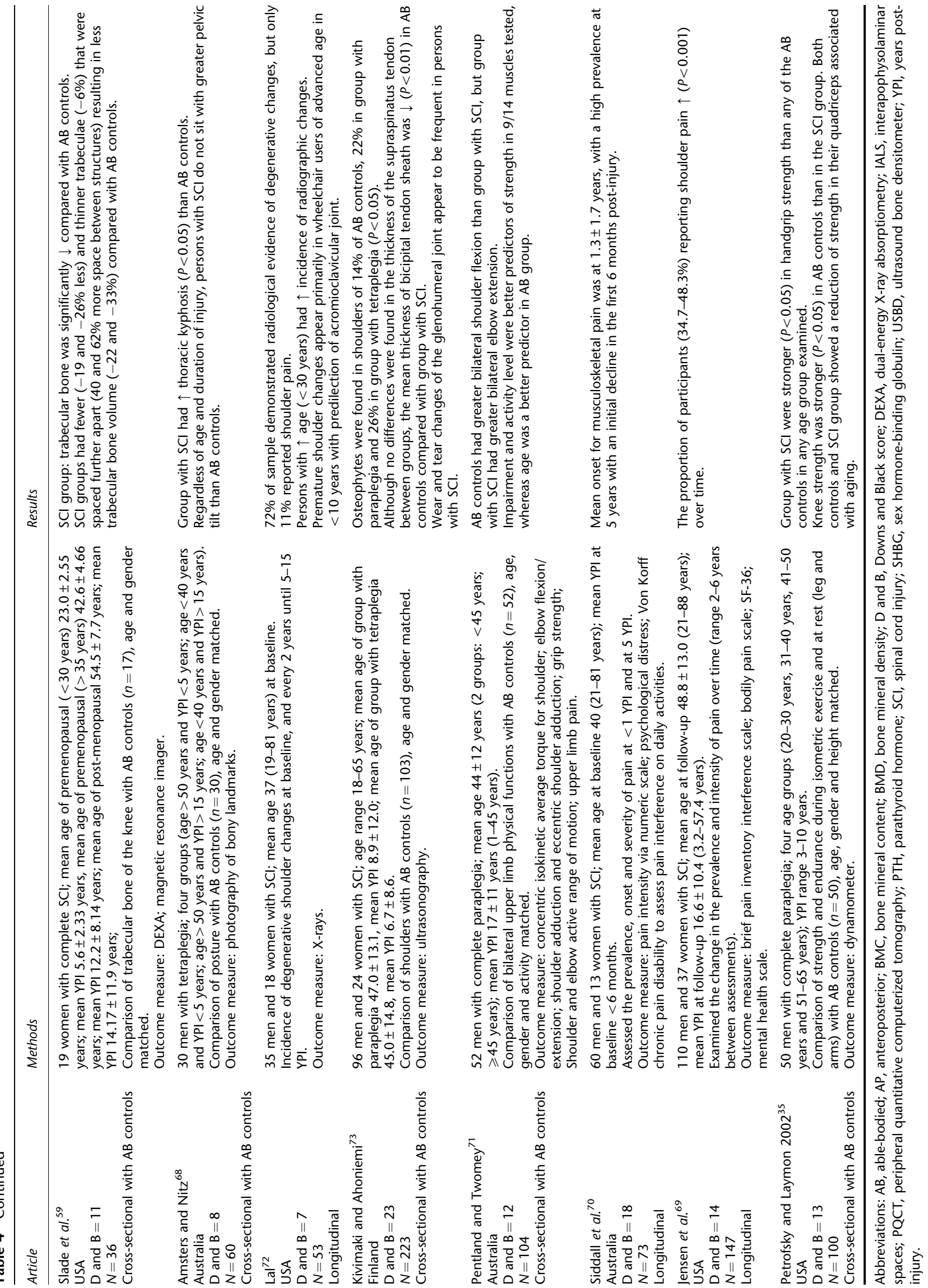


Table 5 Respiratory system

\begin{tabular}{|c|c|c|}
\hline Article & Methods & Results \\
\hline $\begin{array}{l}\text { Bach and Wang } \\
\text { USA } \\
D \text { and } B=12 \\
N=10 \\
\text { Longitudinal }\end{array}$ & $\begin{array}{l}9 \text { men and } 1 \text { woman with tetraplegia; mean age } 41 \pm 12.3 \\
\text { (34-77 years); mean YPI } 7.7 \pm 5.8 \text { ( } 6 \text { months-19 years). } \\
\text { Comparison of oxygen desaturation of SCl at baseline with } \\
\text { 5-year follow-up. } \\
\text { Outcome measure: pulse oximetry. }\end{array}$ & $\begin{array}{l}\text { At baseline, } 6 \text { subjects had desaturation below } \\
90 \% \text {. At follow-up, } 5 \text { subjects had an increased } \\
\text { number of transient nocturnal oxygen } \\
\text { desaturations. }\end{array}$ \\
\hline $\begin{array}{l}\text { Cahan et al. } \\
\text { Australia } \\
D \text { and } B=12 \\
N=28 \\
\text { Cross-sectional with } A B \\
\text { controls }\end{array}$ & $\begin{array}{l}16 \text { men with tetraplegia; mean age } 49 \pm 15 \text { ( } 23-64 \text { years); } \\
\text { mean YPI } 14 \pm 10 \text { ( } 1-32 \text { years). } \\
\text { Comparison of oxygen desaturation with } \mathrm{AB} \text { controls }(n=12) \text {, } \\
\text { age and gender matched. } \\
\text { Outcome measure: pulse oximetry. }\end{array}$ & $\begin{array}{l}6 \text { patients with tetraplegia had } \downarrow \text { in oxygen } \\
\text { saturation levels below the normative range, } \\
\text { indicative of SDB. }\end{array}$ \\
\hline $\begin{array}{l}\text { Biering-Sorensen and } \\
\text { Biering-Sorensen }^{76} \\
\text { Denmark } \\
D \text { and } B=16 \\
N=747 \\
\text { Cross-sectional with } A B \\
\text { controls }\end{array}$ & $\begin{array}{l}331 \text { men and } 77 \text { women; mean age } 42.5 \pm 14.1 \text { (17-86 } \\
\text { years); mean YPI } 12.1 \pm 6.3(2.5-45.1 \text { years). } \\
\text { Comparison of oxygen desaturation with AB controls } \\
\text { ( } n=339) \text { when awake and asleep, age and gender matched. } \\
\text { Outcome measure: nordic sleep questionnaire. }\end{array}$ & $\begin{array}{l}\text { Subjects with } \mathrm{SCl} \text { snored more often }(P<0.00001) \text {, } \\
\text { louder }(P=0.013) \text {, for more years }(P=0.011) \text { and } \\
\text { started at younger ages }(P<0.00001) \text { compared } \\
\text { with } A B \text { controls. }\end{array}$ \\
\hline $\begin{array}{l}\text { Loveridge et al. }{ }^{77} \\
\text { Canada } \\
D \text { and } B=11 \\
N=24 \\
\text { Cross-sectional with } A B \\
\text { controls }\end{array}$ & $\begin{array}{l}6 \text { men with acute } \mathrm{SCl} \text {; mean age } 30 \pm 11 \text {; for persons } \\
\text { with tetraplegia; mean age } 32.6(21-50 \text { years); mean YPI } 38.6 \\
\text { months. } \\
\text { Comparison of lung function and breathing patterns with AB } \\
\text { controls ( } n=18) \text { in both sitting and supine positions, age and } \\
\text { gender matched. Breathing function was assessed at } 3,6 \text { and } \\
>12 \text { months post-injury. } \\
\text { Outcome measure: lung function parameters including, force } \\
\text { vital capacity, inspiratory capacity, residual volume, forced } \\
\text { expiratory capacity, functional residual capacity and } \\
\text { maximum inspiratory mouth pressure; breathing pattern } \\
\text { indicators including, Inspiratory time, tidal volume and } \\
\text { expiratory time. }\end{array}$ & $\begin{array}{l}\text { Seating position resulted in greater stress on the } \\
\text { respiratory system and breathing patterns in the } \\
\text { group with tetraplegia compared with the } A B \\
\text { control group. } \\
\text { Over time, breathing patterns of the group with } \\
\text { tetraplegia improved and were comparable to } \\
\text { those of the } A B \text { control group. }\end{array}$ \\
\hline
\end{tabular}

Abbreviations: AB, able-bodied; D and B, Downs and Black score; SCI, spinal cord injury; SDB, sleep disordered breathing; YPI, years post-injury.

\section{Discussion}

A majority of the articles (64\%) in this review were on the effects of aging with a SCI on the cardiovascular, endocrine and musculoskeletal systems, which provided limited level 2 and 4 evidence, and a large proportion of level 5 evidence, in support of the premature aging hypothesis of these systems. Fewer studies (5\%) were found on the respiratory system, which provide limited level 4 and 5 evidence that this system is negatively impacted by aging after SCI. Only two level 5 studies (3\%) provided support for the immune system. The studies (20\%) on the genitourinary and gastrointestinal systems provide limited level 4 and 5 evidence on the negative effects of aging but do not appear to suggest premature aging. Similarly, level 2 and 4 evidence (3\%) for the skin and subcutaneous tissues also does not suggest premature aging. The level 4 evidence $(5 \%)$ on the nervous system provides some insight on the role of age and YPI, but no evidence to support or denounce the premature aging hypothesis.

\section{Cardiovascular and endocrine systems}

The evidence reviewed appears to support the hypothesis that there is premature aging of the cardiovascular and endocrine systems after SCI. The predisposition to carbohydrate and lipid abnormalities is thought to be largely a consequence of extreme inactivity, and the constellation of metabolic findings (that is, hormone growth hormone deficiency, testosterone deficiency) appears to occur prematurely in persons with SCI. $^{2}$ However, some caution is warranted when interpreting the findings of studies that used standard body mass index values to predict outcomes (that is, Liang et al. ${ }^{29}$ ), which have been shown to be inappropriate for persons with SCI. ${ }^{44}$ As well, all the identified studies for these systems only provided level 5 evidence that reserve capacity is compromised. Hence, higher levels of evidence are needed to provide stronger support for the hypothesis of premature aging.

\section{Immune system}

With regard to immune functioning after SCI, the identified studies indicate that the system is compromised compared with $\mathrm{AB}$ controls, ${ }^{48,49}$ suggesting reduced reserve capacity, but do not clarify whether chronological age (including age of onset) or YPI are significant factors. Given the lack of studies with large sample sizes or with longitudinal designs, further work is strongly needed to determine how aging with SCI impacts this system.

\section{Musculoskeletal system}

The musculoskeletal system provides obvious signs of reduced reserve capacity, and thus suggests premature aging. In general, the identified studies provide evidence for rapid 
Table 6 Skin and subcutaneous tissues

\begin{tabular}{|c|c|c|}
\hline Article & Methods & Results \\
\hline $\begin{array}{l}\text { Rodriguez and Claus-Walker } \\
\text { USA } \\
D \text { and } B=8 \\
N=15 \\
\text { Cross-sectional with } A B \text { controls }\end{array}$ & $\begin{array}{l}10 \text { men with } \mathrm{SCl} \text {; age range } 14-50 \text { years; } \mathrm{YPI}<6 \\
\text { months. } \\
\text { Comparison of skin degradation with } \mathrm{AB} \text { controls } \\
(n=5) \text {, age and gender matched. } \\
\text { Outcome measure: glu-gal } \mathrm{Hyl} \text { and gal } \mathrm{Hyl} \text { from urine } \\
\text { samples. }\end{array}$ & $\begin{array}{l}\text { Although not statistically significant, the concentration } \\
\text { of Glu-gal } \mathrm{Hyl} \text { and gal Hyl were consistent, whereas } \\
\text { the group with SCl had a very wide range of values. }\end{array}$ \\
\hline $\begin{array}{l}\text { Rodriguez and } \text { Garber }^{79} \\
\text { USA } \\
D \text { and } B=15 \\
N=60 \\
\text { Longitudinal }\end{array}$ & $\begin{array}{l}60 \text { men with } \mathrm{SCl} \text {; with at least } 1 \text { past stage II pressure } \\
\text { ulcer; age range } 22-49 \text { years; } \mathrm{YPI}<1 \text { year. } \\
\text { Monitored changes in skin metabolism for } 2 \text { years in } \\
\text { relation to pressure ulcer symptoms. } \\
\text { Outcome measure: } 24-\mathrm{h} \text { urine sample every } 4-6 \text { weeks } \\
\text { used to determine concentrations of glu-gal Hyl, gal } \\
\mathrm{Hyl} \text {, calcium and creatinine. }\end{array}$ & $\begin{array}{l}\text { Subjects with sustained elevated concentration of } \\
\text { glu-gal Hyl ( }>100 \mu \text { mole/g creatinine) were } \\
\text { significantly more likely to develop pressure ulcers. } \\
\text { More smokers than non-smokers developed ulcers. } \\
\text { The majority of persons who developed ulcers had } \\
\text { injuries of T6 and above. }\end{array}$ \\
\hline
\end{tabular}

Abbreviations: $\mathrm{AB}$, able-bodied; D and B, Downs and Black score; $\mathrm{SCl}$, spinal cord injury; YPI, years post-injury.

bone loss, and particularly so in the pelvis and lower limb regions during the acute stage post-SCI. ${ }^{51,52,55,98}$ Further, these losses may be greater for older persons, ${ }^{54}$ and women with SCI, ${ }^{57}$ and is evident in both bone mineral density (amount of matter per cubic centimeter of bones) and content (bone mass). Bone geometric changes ${ }^{50,64}$ have been also been shown post-SCI, however, these changes may be independent of chronological age and YPI. ${ }^{59}$

There is evidence that endocrine changes may be contributing to the losses in bone density. ${ }^{55,62,64-66}$ It is thought that altered bone structure and microarchitecture because of $\mathrm{SCI}^{50,56,58,59}$ leads to impaired calcium and phosphate metabolism and the parathyroid hormone-vitamin D axis. ${ }^{5,62,64-66}$ These changes have been shown to contribute to premature onset of osteoporosis and increased risk for fracture in total and regional sites following SCI when compared with the $\mathrm{AB}$ population, ${ }^{55-58,60-63}$ which may be more related to YPI than chronological age. ${ }^{53,57}$ Age of SCI onset, however, may be an influential factor on the extent of the decline in bone loss, ${ }^{57,58,60}$ as age-related factors may become less important on changes in bone mass when an individual reaches a certain chronological age threshold (that is, 60 years). At this point, other factors (that is, immobilization) affecting bone mass may become more prominent. However, there is evidence that the lumbar spine is not adversely affected by aging with SCI, ${ }^{54,55,57,60-62,67}$ and postural changes are also independent of age and YPI. ${ }^{68}$ The possibility that the lumbar spine becomes the primary weight-bearing region, along with immobilization, may serve to protect age-related bone loss changes to this region. This does not preclude the possibility that long-term weightbearing on the spine could have long-term adverse effects.

With regard to the upper extremities, the shoulders appear to decline with YPI, ${ }^{69,71-73}$ while handgrip strength and bilateral elbow flexion appear to be spared or even improves with time. ${ }^{35,71}$ As well, the incidence of degenerative shoulder changes after SCI may be higher in persons with advanced age (older than 30 years) who are $<10 \mathrm{YPI}^{72}$ suggesting that degenerative changes may occur earlier than previously thought.

Overall, the identified studies for this system provides us with the clearest picture of the effects of aging for persons with SCI through the support of studies with higher levels of evidence compared with the other body systems, and through lower level studies that noted age group comparisons (that is, Szollar et al. ${ }^{60-62}$ ).

\section{Respiratory system}

Although respiratory complications lead to significant morbidity and mortality in people with $\mathrm{SCI},{ }^{99,100}$ only a few studies were identified for this body system. In general, the incidence of sleep disordered breathing, characterized by sleep apnea and snoring, may be higher in persons with SCI than in the $\mathrm{AB}$ population, ${ }^{75,76}$ and appears to increase with age in persons with tetraplegia. ${ }^{74}$ As well, being in a seated position imposes greater stress on the respiratory system in the acute stage of SCI than the supine position, but may improve at one YPI, to levels more comparable with $\mathrm{AB}$ controls. $^{77}$

Overall, reserve capacity appears to be diminished but it is unclear if breathing patterns change as a result of the injury or because of aging with SCI. Although there are additional factors that can affect respiratory health long term for individuals with SCI, there are several preventative activities that can be done to minimize the aging of the respiratory system, such as not smoking, minimizing exposure to polluted air and controlling body weight. ${ }^{4}$

\section{Skin and subcutaneous tissues}

Pressure ulcers are common among individuals with SCI (20$30 \%$ incidence rate). ${ }^{101}$ Although the primary reasons for cause include pressure, shearing and/or friction because of continuous sitting, it may be that a SCI results in an increase in collagen metabolism, thus elevating susceptibility to pressure ulcers. ${ }^{102,103}$ As well, the presence of glu-gal Hyl, a collagen metabolite, in large concentrations in urine is indicative of the degradation of skin collagen. However, there is no evidence suggesting that glu-gal Hyl excretions increase with age after $\mathrm{SCI}^{79}$ or are higher compared with the $\mathrm{AB}$ population, ${ }^{78}$ suggesting that reserve capacity is not diminished. Although increasing age has been shown to be a risk factor for the development of a pressure ulcer among 


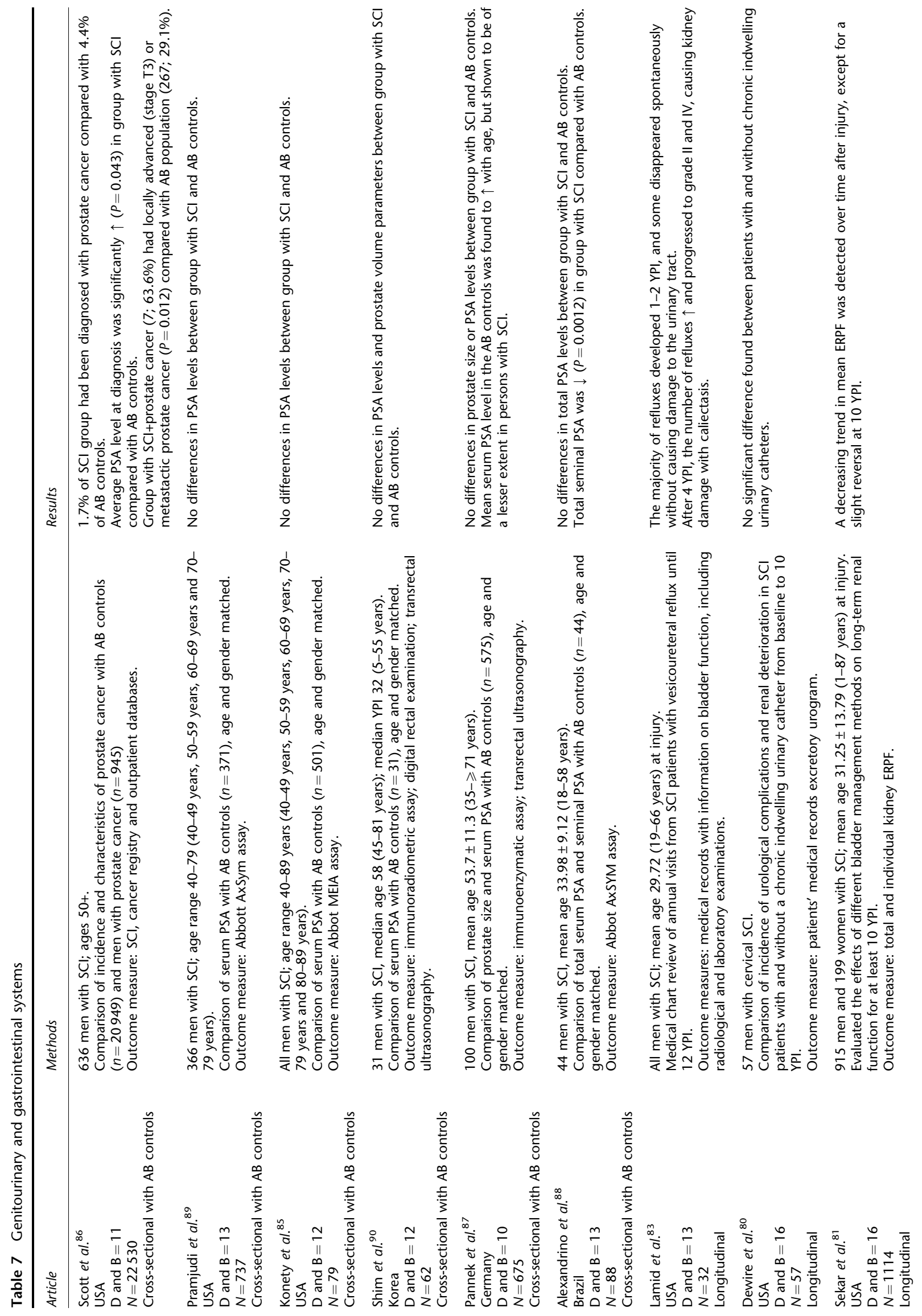




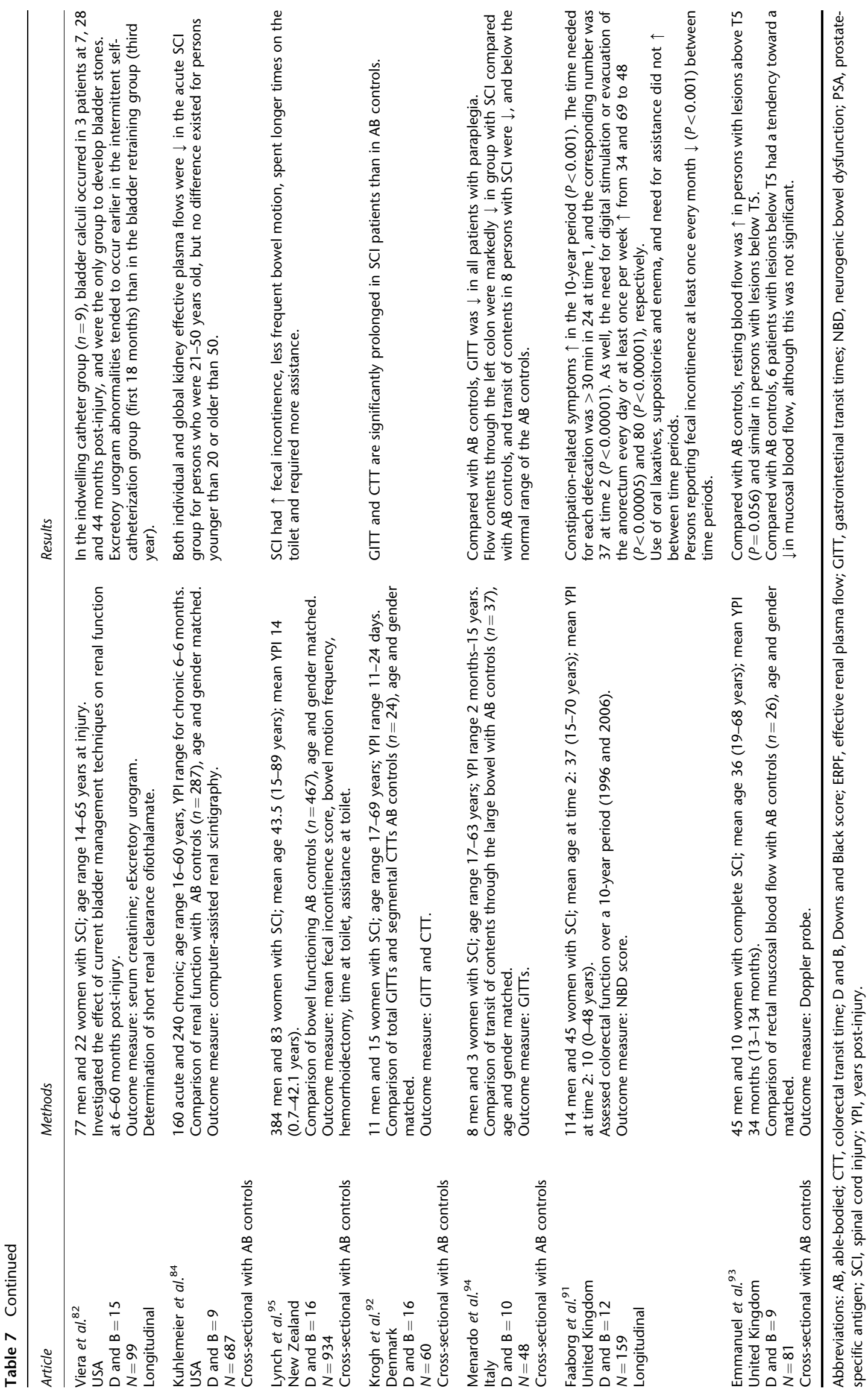


Table 8 Nervous system

\begin{tabular}{|c|c|c|}
\hline Article & Methods & Results \\
\hline $\begin{array}{l}\text { Siddall et al. } \\
\text { Australia } \\
D \text { and } B=18 \\
N=73 \\
\text { Longitudinal }\end{array}$ & $\begin{array}{l}60 \text { men and } 13 \text { women with } \mathrm{SCl} \text {; mean age at baseline } 40 \text { ( } 21-81 \text { years); } \\
\text { mean YPI at baseline }<6 \text { months. } \\
\text { Assessed the prevalence, onset and severity of pain at }<1 \text { YPI and at } 5 \\
\text { YPI. } \\
\text { Outcome measure: pain intensity via numeric scale; psychological } \\
\text { distress; Von Korff chronic pain disability to assess pain interference on } \\
\text { daily activities. }\end{array}$ & $\begin{array}{l}\text { Persons with neuropathic pain early following injury } \\
\text { were likely to continue to experience ongoing and } \\
\text { severe pain. }\end{array}$ \\
\hline $\begin{array}{l}\text { Putzke et al. } \\
\text { USA } \\
\text { D and } B=17 \\
N=270 \\
\text { Longitudinal }\end{array}$ & $\begin{array}{l}210 \text { men and } 60 \text { women with } \mathrm{SCl} \text {; mean age at } 1 \mathrm{YPI} 36.8 \pm 14.3 \text { years. } \\
\text { Examined factors that contribute to pain interference at } 1 \text { and } 2 \mathrm{YPI} \text {. } \\
\text { Outcome measure: short-form } 12 \text {. }\end{array}$ & $\begin{array}{l}\text { Age effect for pain interference was detected } \\
(P<0.001) \text {. Youngest group with } \mathrm{SCl} \text { who reported no } \\
\text { pain interference at both year } 1 \text { and year } 2 \text {, and the } \\
\text { oldest group being those reporting pain interference } \\
\text { at both year } 1 \text { and year } 2 \text {. }\end{array}$ \\
\hline $\begin{array}{l}\text { Rintala et al. } \\
\text { USA } \\
D \text { and } B=18 \\
N=96 \\
\text { Longitudinal }\end{array}$ & $\begin{array}{l}69 \text { men and } 27 \text { women with } \mathrm{SCl} \text {; phase I: male mean age } 40.5 \pm 12.5 \\
(23-70 \text { years); mean YPI } 11.1 \pm 8.8 \text {; female mean age } 37.0 \pm 10.8 \\
\text { (21-61 years); mean YPI } 10.4 \pm 7.2 \text { years). } \\
\text { Assessed the consistency of pain at three (women) and four (men) } \\
\text { measurement points across } 10 \text { years. } \\
\text { Outcome measure: self-report pain characteristics. }\end{array}$ & $\begin{array}{l}\text { Of the } 96 \text { participants, approximately half the men } \\
\text { and three-quarters of women reported consistent pain } \\
\text { across all measurement points. }\end{array}$ \\
\hline $\begin{array}{l}\text { Jensen et al. } \\
\text { USA } \\
D \text { and } B=14 \\
N=147 \\
\text { Longitudinal }\end{array}$ & $\begin{array}{l}110 \text { males and } 37 \text { women with } \mathrm{SCl} \text {; mean age at follow-up } 48.8 \pm 13.0 \\
\text { ( } 21-88 \text { years); mean YPI at follow-up } 16.6 \pm 10.4(3.2-57.4 \text { years). } \\
\text { Examine the change in the prevalence and intensity of pain over } \\
\text { time (range } 2-6 \text { years between assessments). } \\
\text { Outcome measure: brief pain inventory interference scale; bodily pain } \\
\text { scale; SF-36; mental health scale. }\end{array}$ & $\begin{array}{l}\text { Overall, the change or intensity in the prevalence of } \\
\text { pain over time was not significant. }\end{array}$ \\
\hline
\end{tabular}

Abbreviations: AB, able-bodied; D and B, Downs and Black score; YPI, years post-injury.

people with SCI, ${ }^{104}$ there is limited evidence as to whether SCI exacerbates skin degradation because of aging.

\section{Genitourinary system}

Prostate cancer is one of the primary causes of death among men, yet the risk appears to be lower among men with $\mathrm{SCI}^{87,88,90}$ because of impaired testosterone levels. ${ }^{85,89}$ Nonetheless, prostate cancer screening should be encouraged given the possibility that men with SCI who do develop prostate cancer may have poorer outcomes than $\mathrm{AB}$ men. ${ }^{86}$

The evidence ${ }^{80-82}$ indicates that while renal functioning exhibits some significant declines at approximately five YPI, the type of bladder management used by persons with SCI may not be a strong contributor to this decline. It may also be that persons between the ages of 20 and 50 experience a disruption in biological capacity in this system during the acute phase of SCI. More work regarding age of SCI onset and the genitourinary system is needed to help determine the impact of aging. Overall, the evidence does not provide support that this system is prematurely aging following SCI.

\section{Gastrointestinal system}

Neurogenic bowel may also compound aging after SCI, ${ }^{4}$ but some studies did not provide details of the role of age in either the SCI or AB control groups. ${ }^{92}$ Although YPI may not have a significant role, it does appear that constipationrelated problems do increase over time in persons with SCI, and suggests that attention to bowel symptoms should be incorporated into routine follow-up procedures and education. ${ }^{3}$ Similar to the genitourinary system, the evidence on the gastrointestinal system does not provide any evidence of premature aging.

Nervous system

With regard to the nervous system, the only studies that were identified were those related to chronic pain. The clearest finding from these studies is that the presence of pain at an earlier time point after SCI appears to be the best predictor of future pain, and that this is likely does not change significantly over time. ${ }^{69,70,96,97}$ In general, there is a continued dearth of knowledge regarding the aging SCI nervous system.

\section{Summary}

The majority of studies for all the systems provide some important findings regarding the role of chronological age (including age of SCI onset) and YPI, but there is still lack of clarity on how all of these factors affect (individually and in combination) the individual living with SCI over time, and further work is needed to determine if SCI is indeed a model for premature aging across all body systems. As noted, the studies from the musculoskeletal system provide the strongest levels of evidence of premature aging, and even do so with lower levels of evidence by providing age comparisons within studies between SCI and $\mathrm{AB}$ samples. Efforts should be made to do the same for prospective studies for other body systems as well. Overall, it appears that the field of aging with SCI has yet to make significant advances since many of the issues and questions raised over 15 years ago are still relevant today. Although somewhat discouraging, 
the dearth of knowledge in some areas highlights research opportunities that will help to resolve current challenges, and more importantly, provide information to fill many existing gaps.

\section{Limitations}

Information on aging with SCI not published in English may have influenced our findings but were excluded from this review. As well, some articles with relevance may have been missed if aging was not the primary focus.

\section{Conflict of interest}

The authors declare no conflict of interest.

\section{Acknowledgements}

Funding for this project was provided by the Rick Hansen Institute and the Ontario Neurotrauma Foundation. Dr Hitzig receives post-doctoral funding support from the Toronto Rehabilitation Institute, which receives funding under the Provincial Rehabilitation Research Program from the Ministry of Health and Long-Term Care in Ontario. The views expressed do not necessarily reflect those of the Ministry. Salary support/scholarship was provided by the Canadian Institutes of Health Research (JJE, WCM and BMS) and the Michael Smith Foundation for Health Research (JJE).

\section{References}

1 Thompson L, Yakura J. Aging related functional changes in persons with spinal cord injury. Top Spinal Cord Inj Rehabil 2006; 6: 69-82.

2 Bauman WA, Spungen AM. Disorders of carbohydrate and lipid metabolism in veterans with paraplegia or quadriplegia: a model of premature aging. Metabol 1994; 43: 749-756.

3 Charlifue S, Lammertse D. Aging in spinal cord injury. In: Kirshblum S, Campagnolo DI, DeLisa JA (eds). Spinal Cord Medicine. Lippincott, Williams \& Wilkins: Philadelphia, 2002, pp 409-423.

4 Whiteneck GG, Charlifue SW, Gerhart KA, Lammertse DP, Manley S, Menter RR et al., (eds). Aging with Spinal Cord Injury. Demos Publications: New York, 1993.

5 Capoor J, Stein AB. Aging with spinal cord injury. Phys Med Rehabil Clin N Am 2005; 16: 129-161.

6 Kemp B, Thompson L. Aging and spinal cord injury: medical, functional, and psychosocial changes. SCI Nursing 2002; 19: $51-60$.

7 Adkins RH. Research and interpretation perspectives on aging related physical morbidity with spinal cord injury and brief review of systems. Neuro Rehabil 2004; 19: 3-13.

8 Pickett GE, Campos-Benitez M, Keller JL, Duggal N. Epidemiology of traumatic spinal cord injury in Canada. Spine 2006; 31: 799-805.

9 Furlan JC, Kattail D, Fehlings M. The impact of co-morbidities on age-related differences in mortality after acute traumatic spinal cord injury. J Neurotrauma 2009; 26: 1361-1367.

10 Whiteneck GG, Charlifue SW, Frankel HL, Fraser MH, Gardner BP, Gerhart KA. Mortality, morbidity and psychosocial outcomes of persons spinal cord injured more than 20 years ago. Paraplegia 1992; 30: 617-630.

11 Ballinger DA, Rintala DH, Hart KA. The relation of shoulder pain and range-of-motion problems to functional limitations, disability, and perceived health of men with spinal cord injury: a multifaceted longitudinal study. Arch Phys Med Rehabil 2000; 81: $1575-1581$.

12 Weitzenkamp DA, Jones RH, Whiteneck GG, Young DA. Aging with spinal cord injury: cross-sectional and longitudinal effects. Spinal Cord 2001; 39: 201-309.

13 Garland DE, Stewart CA, Adkins RH, Hu SS, Rosen C, Liotta FJ et al. Osteoporosis after spinal cord injury. J Orthop Res 1992; 10: 371-378.

14 Brenes G, Dearwater S, Shapera R, LaPorte RE, Collins E. High density lipoprotein cholesterol concentrations in physically active and sedentary spinal cord injured patients. Arch Phys Med Rehabil 1986; 67: 445-450.

15 Bauman WA, Khan NN, Grimm DR. Risk factors for atherogenesis and cardiovascular autonomic function in persons with spinal cord injury. Spinal Cord 1999; 37: 601-616.

16 McKinley WO, Jackson AB, Cardenas DD, DeVivo MJ. Long-term medical complications after traumatic spinal cord injury: a regional model systems analysis. Arch Phys Med Rehabil 1999; 80: 1402-1410.

17 Madersbacher G, Oberwalder M. The elderly para- and tetraplegic: special aspects of the urological care. Paraplegia 1987; 4: 318-323.

18 Apstein MD, Dalecki-Chipperfield K. Spinal cord injury is a risk factor for gallstone disease. Gastroeneterology 1987; 92: 966-988.

19 Charlifue SW, Gerhart K, Whiteneck GG. Conceptualizing and quantifying functional change: an examination of aging with spinal cord injury. Top Geriatr Rehabil 1998; 13: 35-48.

20 Eng JJ, Teasell RW, Miller WC. Spinal cord injury rehabilitation evidence: methods of the SCIRE systematic review. Top Spinal Cord Inj Rehabil 2007; 13: 1-10.

21 Downs SH, Black N. The feasibiilty of creating a checklist for the assessment of the methodological quality both of randomised and non-randomised stduies of health care interventions. J Epidemiol Community Health 1998; 52: 377-384.

22 Staus SE, Richardson WS, Glasziou P, Haynes RB. Evidence-Based Medicine: How to Practice and Teach EBM, 3rd edn. Elsevier Churchill Livingstone: Toronto, 2005.

23 Bauman WA, Adkins RH, Spungen AM, Waters RL, Kemp B, Herbert V. Levels of plasma homocysteine in persons with spinal cord injury. J Spinal Cord Med 2001; 24: 81-86.

24 Stampfer MJ, Malilinow R, Willett WC, Newcomer LM, Upson B, Ullmann D et al. A prospective study of plasma homocysteine and risk of myocardial infarction in US physicians. JAMA 1992; 268: 877-881.

25 Clarke R, Daly L, Robinson K, Naughten E, Cahalane S, Fowler B et al. Hyperhomocysteinemia: an independent risk factor for vascular disease. N Eng J Med 1991; 324: 1149-1155.

26 Bauman WA, Spungen AM, Zhong YG, Mobbs CV. Plasma leptin is directly related to body adiposity in subjects with spinal cord injury. Horm Metab Res 1996; 28: 732-736.

27 Bauman WA, Adkins RH, Herbert P, Schechter C, Smith D, Kemp BJ et al. Is immobilization associated with an abnormal lipoprotein profile? Observations from a diverse cohort. Spinal Cord 1999; 37: 485-493.

28 Zlotolow SP, Levy E, Bauman WA. The serum lipoprotein profile in veterans with paraplegia: the relationship to nutritional factors and body mass index. J Am Para Soc 1992; 15: 158-162.

29 Liang H, Chen D, Wang Y, Rimmer JH, Braunschweig CL. Different risk factor patterns for metabolic syndrome in men with spinal cord injury compared with able-bodied men despite similar prevalence rates. Arch Phys Med Rehabil 2007; 88: $1198-1204$.

30 Huang TS, Wang YH, Chen S. The relation of serum leptin to body mass index and to serum cortisol in men with spinal cord injury. Arch Phys Med Rehabil 1998; 81: 1582-1586.

31 Huang TS, Wang YH, Chiang HS, Lien YN. Pituitary-testicular and pituitary-thyroid axes in spinal cord-injured males. Metabol 1993; 42: 516-521.

32 Wang TD, Wang YH, Hung TS, Su TC, Pan SL, Chen SY. Circulating levels of markers of inflammation and endothelial 
activation are increased in men with chronic spinal cord injury. J Formos Med Assoc 2007; 106: 919-928.

33 Demirel SD, Demirel G, Tükek T, Erk O, Yilmaz H. Risk factors for coronary heart disease in patients with spinal cord injury in Turkey. Spinal Cord 2001; 39: 134-138.

34 Orakzai SH, Orakzai RH, Ahmadi N, Agrawal N, Bauman WA, Yee $\mathrm{F}$ et al. Measurement of coronary artery calcification by electron beam computerized tomography in persons with chronic spinal cord injury: evidence for increased atherosclerotic burden. Spinal Cord 2007; 45: 775-779.

35 Petrofsky JS, Laymon M. The effect of ageing in spinal cord injured humans on the blood pressure and heart rate responses during fatiguing isometric exercise. Eur J Appl Physiol 2002; 86: 479-486.

36 Yamamoto M, Tajima F, Okawa H, Mizushima T, Umezu Y, Ogata $\mathrm{H}$. Static exercise-induced increase in blood pressure in individuals with cervical spinal cord injury. Arch Phys Med Rehabil 1999; 80: 288-293.

37 Tsitouras PD, Zhong YG, Spungen AM, Bauman WA. Serum testosterone and growth hormone/insulin-like growth factor-I in adults with spinal cord injury. Horm Metab Res 1995; 27: 287-292.

38 Wang YH, Huang TS, Lien IN. Hormone changes in men with spinal cord injuries. Am J Phys Med Rehabil 1992; 71: 328-332.

39 Cheville AL, Kirshblum SC. Thyroid hormone changes in chronic spinal cord injury. J Spinal Cord Med 1995; 18: 227-232.

40 Shetty KR, Sutton CH, Mattson DE, Rudman D. Hyposomatomedinemia in quadriplegic men. Am J Med Sci 1993; 305: 95-100.

41 Bauman WA, Spungen AM, Flanagan S, Zhong YG, Alexander LR, Tsitouras PD. Blunted growth hormone response to intravenous arginine in subjects with spinal cord injury. Horm Metab Res 1994; 26: $152-156$.

42 Jones LM, Legge M, Goulding A. Factor analysis of the metabolic syndrome in spinal cord-injured men. Metabol 2004; 53: 1372-1377.

43 Lavela SL, Weaver FM, Goldstein B, Chen K, Miskevics S, Rajan S et al. Diabetes mellitus in individuals with spinal cord injury or disorder. J Spinal Cord Med 2006; 29: 387-395.

44 Jones LM, Legge M, Goulding A. Healthy body mass index values often underestimate body fat in men with spinal cord injury. Arch Phys Med Rehabil 2003; 84: 1068-1071.

45 Nuhlicek DN, Spurr GB, Barboriak JJ, Rooney CB, El Ghatit EL, Bongrard RD. Body composition of patients with spinal cord injury. Euro J Clin Nut 1988; 42: 765-773.

46 Spungen AM, Wang J, Pierson JRN, Bauman WA. Soft tissue body composition differences in monozygotic twins discordant for spinal cord injury. J Appl Physiol 2000; 88: 1310-1315.

47 Bauman WA, Spungen AM, Wang J, Pierson JRN. The relationship between energy expenditure and lean tissue in monozygotic twin discordant for spinal cord injury. J Rehab Res Dev 2004; 41: 1-8.

48 Campagnolo DI, Keller SE, DeLisa JA, Glick TJ, Sipski ML, Schleifer SJ. Alteration of immune system function in tetraplegics. Am J Phys Med Rehabil 1994; 73: 387-393.

49 Campognolo DI, Bartlett JA, Chatterton RJ, Keller SE. Adrenal and pituitary hormone patterns after spinal cord injury. Am J Phys Med Rehabil 1999; 78: 361-366.

50 de Bruin E, Dietz V, Dambacher MA, Stussi E. Longitudinal changes in bone in men with spinal cord injury. Clin Rehabil 2000; 14: 145-152.

51 de Bruin E, Vanwanseele B, Dambacher MA, Dietz V, Stussi E. Long-term changes in the tibia and radius bone mineral density following spinal cord injury. Spinal Cord 2005; 43: 96-101.

52 Frey-Rindova P, de Bruin ED, Stussi E, Dambacker MA, Dietz V. Bone mineral density in upper and lower extremities during 12 months after spinal cord injury measured by peripheral quantitative computed tomography. Spinal Cord 2000; 38: 26-32.

53 Bauman WA, Spungen AM, Wang J, Pierson RNJ, Schwartz E. Continous loss of bone during chronic immobilization: a monozygotic twin study. Osteoporos Int 1999; 10: 123-127.
54 Chow YW, Inman C, Pollintine P, Sharp CA, Haddawa MJ, El Masry $\mathrm{W}$ et al. Ultrasound bone densitometry and dual energy X-ray absorptiometry in patients with spinal cord injury: a cross-sectional study. Spinal Cord 1996; 34: 736-741.

55 Dauty M, Perrouin Verbe B, Maugars Y, Dubois C, Mathe JF Supralesional and sublesional bone mineral density in spinal cord injuryed patients. Bone 2000; 27: 305-309.

56 Eser P, Frotzler A, Zehnder Y, Wick L, Knecht H, Denoth J et al. Relationship between the duration of paralysis and bone structure: a pQCT study of spinal cord injured individuals. Bone 2004; 34: 869-880.

57 Garland DE, Adkins RH, Stewart CA, Ashford R, Vigil D. Regional osteoporosis in women who have a complete spinal cord injury. J Bone Joint Surg 2001; 83-A: 1195-1200.

58 Kiratli BJ, Smith AE, Nauenberg T, Kallfelz CF, Perkash I. Bone mineral and geometric changes through the femur with immobilization due to spinal cord injury. J Rehabil Res Dev 2000; 37: 225-233.

59 Slade JM, Bickel CS, Modlesky CM, Majumdar S, Dudley GA. Trabecular bone is more deteriorated in spinal cord injured versus estrogen-free menopausal women. Osteoporos Int 2005; 16: 263-272.

60 Szollar SM, Martin EME, Parthemore JG, Sartoris DJ, Deftos LJ. Densitometric patterns of spinal cord injur associated bone loss. Spinal Cord 1997; 35: 374-382.

61 Szollar SM, Martin EME, Parthemore JG, Sartoris DJ, Deftos LJ. Demineralization in tetraplegic and paraplegic man over time. Spinal Cord 1997; 35: 325-328.

62 Szollar SM, Martin EME, Sartoris DJ, Parthemore JG, Deftos LJ. Bone mineral density and indexes of bone metabolism in spinal cord injury. Am J Phys Med Rehabil 1998; 77: 28-35.

63 Vlychou M, Papadaki PJ, Zavras GM, Vasio K, Kelekis N, Malizos $\mathrm{KN}$ et al. Paraplegia-related alterations of bone density in forearm and hip in Greek patients after spinal cord injury. Dis Rehab 2003; 25: 324-330.

64 Finsen V, Indredavik B, Fougner KJ. Bone mineral and hormone status in paraplegics. Paraplegia 1992; 30: 343-347.

65 Vaziri ND, Pandian MR, Segal JL, Winer RL, Eltorai I, Burnnemann BS. Vitamin D, Parathormone and Calcitonin profiles in persons with long-standing spinal cord injury. Arch Phys Med Rehabil 1994; 75: 766-769.

66 Bauman WA, Zhong YG, Schwartz E. Vitamin D deficiency in veterans with chronic spinal cord injury. Metabol 1995; 44: $1612-1616$.

67 Catz A, Reider-Grosswasser I, Gutman I, Gepstein R, Mendelson L. Lumbar spine dimensions in parapareic patients: a 10 year follow-up study. Paraplegia 1992; 30: 729-733.

68 Amsters D, Nitz J. The consequences of increasing age and duration of injury upon the wheelchair posture of men with tetraplegia. Int J Rehabil 2006; 29: 347-349.

69 Jensen MP, Hoffman AJ, Cardenas DD. Chronic pain in individuals with spinal cord injury: a survey and longitudinal study. Spinal Cord 2005; 43: 704-712.

70 Siddall PJ, McClelland JM, Rutkowski SB, Cousins MJ. A longitudinal study of the prevalence and characteristics of pain in the first 5 years following spinal cord injury. Pain 2003; 103: 249-257.

71 Pentland WE, Twomey L. Upper limb function in persons with long term paraplegia and implications for independence. Paraplegia 1994; 32: 211-218.

72 Lal S. Premature degenerative shoulder changes I spinal cord injury patients. Spinal Cord 1998; 36: 186-189.

73 Kivimäki J, Ahoniemi E. Ultrasonographic findings in shoulders of able-bodied, paraplegic and tetraplegic subjects. Spinal Cord 2008; 46: 50-52.

74 Bach JR, Wang TG. Pulmonary function and sleep disordered breathing in patients with traumatic tetraplegia: a longitudinal study. Arch Phys Med Rehabil 1994; 75: 279-284.

75 Cahan C, Gothe B, Decker MJ, Arnold JL, Strohl KP. Arterial oxygen saturation over time and sleep studies in quadriplegic patients. Paraplegia 1993; 31: 172-179.

76 Biering-Sorensen F, Biering-Sorensen M. Sleep disturbances in the spinal cord injured: an epidemiological questionnaire 
investigation, including a normal population. Spinal Cord 2001; 39: 505-513.

77 Loveridge B, Sanii R, Dubo HI. Breathing pattern adjustments during the first year following cervical spinal cord injury. Paraplegia 1992; 30: 479-488.

78 Rodriguez GP, Claus-Walker J. Measurement of hydroxylysine glycosides in urine and its application to spinal cord injury. J Chroma 1984; 308: 65-73.

79 Rodriguez GP, Garber SL. Prospective study of pressure ulcer risk in spinal cord injury patients. Paraplegia 1994; 32: 150-158.

80 DeWire DD, Owens RS, Anderson GA, Gottlieb MS, Lepor H. A comparison of the urological complications associated with long-term management of quadriplegics with and without chronic indwelling urinary catheters. J Urol 1992; 147: 1069-1072.

81 Sekar P, Wallace DD, Waites KB, DeVivo MJ, Lloyd LK, Stover SL et al. Comparison of long-term renal function after spinal cord injury using different urinary management methods. Arch Phys Med Rehabil 1997; 78: 992-997.

82 Viera A, Merritt JL, Erickson RP. Renal function in spinal cord injury: a preliminary report. Arch Phys Med Rehabil 1986; 67: 257-259.

83 Lamid S. Long-term follow-up of spinal cord injury patients with vesicoureteral reflux. Paraplegia 1988; 26: 27-34.

84 Kuhlemeier KV, McEachran AB, Lloyd K, Stover SL, Tauxe WN, Dubovsky EV et al. Renal function after acute and chronic spinal cord injury. J Urol 1984; 131: 439-445.

85 Konety BR, Nguyen TT, Brenes G, Lewis N, Saul M, Nelson JB et al. Evaluation of the effect of spinal cord injury on serum PSA levels. Urology 2000; 56: 82-86.

86 Scott Sr PA, Perkash I, Mode D, Wolfe VA, Terris MK. Prostate cancer diagnosed in spinal cord-injured patients is more commonly advanced stage than in able-bodied patients. J Urol 2003; 63: 509-512.

87 Pannek J, Berges RR, Cubick G, Meindl R, Senge T. Prostrate size and PSA serum levels in male patients with spinal cord injury. Urology 2003; 62: 845-848.

88 Alexandrino AP, Rodrigues MAF, Matsuo T. Evaluation of serum and seminal levels of prostate specific antigen in men with spinal cord injury. J Urol 2004; 171: 2230-2232.

89 Pramudji CK, Mtuchnik SE, DeConcini D, Boone TB. Prostate cancer screening with prostrate specific antigen in spinal cord injured men. J Urol 2002; 167: 1303-1305.

90 Shim HB, Kim YD, Jung TY, Lee JK, Ku JH. Prostatespecific antigen and prostate volume in Korean men with spinal cord injury: a case-control study. Spinal Cord 2008; 46: $11-15$
91 Faaborg PM, Christensen P, Finnerup N, Laurberg S, Krogh K. The pattern of colorectal dysfunction changes with time since spinal cord injury. Spinal Cord 2008; 46: 234-238.

92 Krogh K, Mosdal C, Laurberg S. Gastrointestinal and segmental colonic transit times in patients with acute and chronic spinal cord lesions. Spinal Cord 2000; 38: 615-621.

93 Emmanuel AV, Chung EAL, Kamm MA, Middleton F. Relationship between gut-specific autonomic testing and bowel dysfunction in spinal cord injury patients. Spinal Cord 2009; 47: 623-627.

94 Menardo G, Bausano G, Corazziri E, Fazio A, Marangi A, Genta V et al. Large-bowel transit in paraplegic patients. Dis Col Rect 1987; 30: 924-928.

95 Lynch AC, Wong C, Anthony A, Dobbs BR, Frizelle FA. Bowel dysfunction following spinal cord injury: a description of bowel function in a spinal cord-injured population and comparison with age and gender matched controls. Spinal Cord 2000; 38: 717-723.

96 Putzke JD, Richards JS, Hicken BL, DeVivo MJ. Interference due to pain following spinal cord injury: important predictors and impact on quality of life. Pain 2002; 100: 231-242.

97 Rintala DH, Hart KA, Priebe MM. Predicting consistency of pain over a 10-year period in persons with spinal cord injury. J Rehab Res Dev 2004; 41: 75-88.

98 Garland DE, Adkins RH, Scott M, Singh H, Massih M, Stewart CA. Bone loss at the os calcis compared with bone loss at the knee in individuals with spinal cord injury. I Spinal Cord Med 2004; 27: 207-211.

99 Cotton BA, Pryor JP, Chinwalla I, Wiebe DJ, Reilly PM, Schwab CW. Respiratory complications and mortality risk associated with thoracic spine injury. J Trauma 2005; 59: 400-409.

100 DeVivo MJ, Black KJ, Stover SL. Causes of death during the first 12 years after spinal cord injury. Arch Phys Med Rehabil 1993; 74: 248-254.

101 Byrne DW, Salzberg CA. Major risk factors for pressure ulcers in the spinal cord disabled: a literature review. Spinal Cord 1996; 34: 255-263.

102 Claus-Walker J, Halstead LS. Metabolic and endocrine changes in spinal cord injury: III. Less quanta of sensory impact plus bedrest and illness. Arch Phys Med Rehabil 1982; 63: 628-631.

103 Claus-Walker J, Halstead LS. Metabolic and endocrine changes in spinal cord injury: IV. Compounded neurologic dysfunction. Arch Phys Med Rehabil 1982; 63: 632-638.

104 Salzberg CA, Bryne DW, Cayten CG, van Niewerburgh P, Murphy JG, Viehbeck M. A new pressure ulcer risk assessment scale for individuals with spinal cord injury. Am J Phys Med Rehabil 1996; 75: 96-104. 